\title{
SISTEM PENGELOLAAN DANA ZAKAT PROFESI PADA BADAN AMIL ZAKAT NASIONAL KABUPATEN POLEWALI MANDAR
}

\section{Management System Of Professional Zakat Funds In The National Amil Zakat Agency Of Polewali Mandar District}

\author{
Fauziah \\ Email : fauziah@ddipolman.ac.id \\ Ekonomi Syariah_Fakultas Ekonomi dan Bisnis Islam_Institut Agama Islam DDI \\ Polewali Mandar \\ Sappeami \\ Email : sappeamihamzah@gmail.com \\ Ekonomi Syariah_Fakultas Ekonomi dan Bisnis Islam_Institut Agama Islam DDI \\ Polewali Mandar \\ Muh. Musyawwir \\ Email : sawirawi97@gmail.com \\ Ekonomi Syariah_Fakultas Ekonomi dan Bisnis Islam_Institut Agama Islam DDI \\ Polewali Mandar
}

\begin{abstract}
ABSTRAK
Zakat profesi menjadi bahan pembahasan dan telah banyak di lakukan oleh berbagai pihak. Peraturan Bupati Polewali Mandar Provinsi Sulawesi Barat telah mengeluarkan peraturan Bupati Nomor 9 tahun 2019 tetang tata cara pengumpulan zakat profesi bagi Aparatur Sipil Negara di Kabupaten polewali mandar. Bedasarkan hal tersebut artikel ini membahas sistem pengelolaan dana zakat profesi pada badan amil zakat nasional kabupaten polewali mandar. Penelitian lapangan (Field Research) digunakan untuk melakukan penelitian pendekatan kualitatif deskriptif. Data diperoleh melalui wawancara, dokumentasi serta observasi. Kemudian dilakukan reduksi data, penyajian data serta verifikasi data. Hasil penelitian menunjukkan bahwa pengelolaan dana zakat profesi oleh BASNAS Kabupaten Polewali Mandar belum optimal di bidang pengumpulan. BAZNAS Kabupaten Polewali Mandar berkoordinasi dengan seluruh UPZ setiap SKPD, camat, serta lurah dalam pengumpulan zakat profesi, meskipun begitu, BAZNAS harus meningkatkan sosialisasi untuk menungkatkan pengumpulan dari profesi lainnya seperti advokat, kontraktor, dan lain-lain. Penditribusian dan pendayagunaan dana zakat profesi di BAZNAS Kabupaten Polewali Mandar telah mengedepankan kepatuhan terhadap segala regulasi yang ditetapkan selama hal itu tidak melanggar hukum syara ${ }^{e e}$. Jumlah pendistribusian zakat profesi di BAZNAS Kabupaten Polewali Mandar sudah sangatbaik, yaitu sekitar 90\%
\end{abstract}


dari total pengumpulan setiap tahunnya. Penyaluran zakat direncakan dengan baik dan berkoordinasi dengan pihak yang terkait. Pendayagunaan zakat profesi di Kabupaten Polewali Mandar pada umumnya untuk menanggulangan musibah dan pembinaan sumber daya manusia, serta pengembangan ekonomi.

Kata Kunci: Pengelolaan, dana, zakat, profesi

\begin{abstract}
Zakat on profession is a subject of discussion and has been widely practiced by various parties. The Polewali Mandar Regent Regulation of West Sulawesi Province has issued Regent Regulation Number 9 of 2019 concerning procedures for collecting professional zakat for State Civil Servants in Polewali Mandar Regency. Based on this, this article discusses the professional zakat fund management system at the national amil zakat agency, Polewali Mandar district. Field research (Field Research) is used to conduct a descriptive qualitative research approach. Data obtained through interviews, documentation and observation. Then performed data reduction, data presentation and data verification. The results showed that the management of professional zakat funds by BASNAS Polewali Mandar Regency was not optimal in the field of collection. BAZNAS Polewali Mandar Regency coordinates with all UPZs for each SKPD, sub-district, and village head in collecting professional zakat, however, BAZNAS must increase socialization to increase collection from other professions such as advocates, contractors, and others. The distribution and utilization of professional zakat funds in BAZNAS Polewali Mandar Regency has prioritized compliance with all established regulations as long as it does not violate syara 'law. The amount of professional zakat distribution in BAZNAS Polewali Mandar Regency is very good, which is around $90 \%$ of the total collection every year. Zakat distribution is well planned and coordinated with related parties. Utilization of professional zakat in Polewali Mandar Regency in general is to cope with calamities and develop human resources, as well as economic development.
\end{abstract}

Keywords: Management, funds, zakat, profession

\title{
PENDAHULUAN
}

Zakat dalam segi istilah adalah harta tertentu yang wajib dikeluarkan oleh orang yang beragama Islam dan diberikan kepada golongan yang berhak menerimanya (fakir miskin dan sebagainya). Zakat dari segi bahasa berarti bersih,suci, subur,berkatdan berkembang.Menurut ketentuan yang telah ditetapkan oleh syariat Islam. Zakat atau yang oleh beberapa pihak menyebutnya sebagai filantrophi Islam telah menjadi isu yang sangat penting dalam upaya mengikis kemiskinan, sehingga bisa mewujudkan masyarakat yang sejahtera. Pada masa sekarang pembicaraan tentangzakat khususnya zakat profesi telah menjadi bahan penting dalam meningkatkan kesejahteraan umat 
zakat profesi adalah zakat yang dikeluarkan dari penghasilan profesi (hasil profesi) bila telah mencapai nisab.Profesi yang dimaksud mencakup profesi pegawai negeri atau swasta dan lain-lain (Andri Soemitra, 2013). Zakat profesi tergolong jenis baru dalam kategorisasi harta yang wajib dikeluarkan zakatnya. secara garis besar zakat profesi dapat diartiakan sebagai zakat yang dipungut/diperoleh dari upah, gaji, honorarium karyawan dan usaha profesional seperti penghasilan Pegawai Negeri Sipil, seorang dokter, insinyur, guru, dan lain-lain yang telah mencapai nisab.

Permasalahan tentang zakat terus meningkat mulai dari penerimaan hingga kepenyaluran zakat. Pemerintah telah memberikan ketegasan dibuktikan adanya Undang-undang zakat,tetapi masyarakat yang kurang merespon. Salah satu keandalanya adalah kurangnya pengetahuan masyarakat tentang kewajiban dalam membayar zakat. Sedangkan kewajiban membayar zakat itu dituliskan dalam alQur'an Q.S at-Taubah ayat 103 yang Terjemahnya:

"Ambillah zakat dari harta mereka,guna membersihkan mensucikan mereka dan mendoalah untuk mereka. Sesungguhnya doamu itu (menumbuhkan) ketenteraman jiwa bagi mereka. dan Allah Maha mendengar, Maha mengetahui".

Adanya lembaga pengelola zakat yang berada ditengah-tengah masyarakat maka dapat menjegah kecemburuan antara orang kaya dan orang miskin, karena zakat merupakan salah satu bagian dari aturan jaminan sosial dalam agama Islam, dimana aturan jaminan sosial ini tidak dikenal berat, kecuali dalam ruang lingkup yang sempit yaitu jaminan pekerjaan, dengan menolong kelompok orang yang lemah dan fakir (Yusf Qardawi, 2015).

Terciptanya kondisi masyarakat yang harmonis dan hilangnya faktor penyebab rendahnya produktivitas, pertumbuhan dan pengembangan potensi sumber daya masyarakat adalah cita-cita umat Islam yang mesti diperjuangkan, karena masalah kemiskinan merupakan tanggung jawab bersama.

Berkaitan dengan masalah tersebut, sesungguhnya Allah telah menetapkan suatu bagian tertentu yang tetap pasti, bagi fakir miskin, yaitu zakat. Dengan demikian, sesungguhnya umat Islam memiliki potensi yang besar untuk mengatasidan 
menghilangkan kemiskinan. Setidaknya dana zakat dapat membantu pemerintah dalam mengatasi berbagai masalah sosial. Apabila dalam setiap suatu pekerjaan ibadah mengandung segi-segi sosial, maka dalam zakat ini sangat identik dengan fungsi sosialnya.

Maksimalisasi penyaluran zakat merupakan salah satu faktor suksesnya peran zakat dalam memberantas kemiskinan, Pengelolaan zakat dilaksanakan dengan didasarkan pada sejumlah asas, yaitu syariat Islam, amanat (pengelola zakat harus dapat dipercaya), kemanfaatan (pengelolaan zakat dilakukan untuk memberikan manfaat yang sebesar-besarnya bagi mustahik), keadilan (pengelolaan zakat dalam pendistribusiannya dilakukansecara adil), kepastian hukum (dalam pengelolaan zakat terdapat jaminan kepastian hukum bagi mustahik dan muzzaki), terintegrasi (pengelolaan zakat dilaksanakan secara hirarkis dalam upaya meningkatkan pengumpulan, pendistribusian, dan pendayagunaan zakat), dan akuntanbilitas (pengelolaan zakat dapat dipertanggungjawabkan dan diakses oleh masyarakat). (Andri Soemitra, 2016).

Selain zakat fitrah dan zakat maal seiring berkembangnya zaman zakat profesi menjadi bahan pembahasan dan telah banyak di lakukan oleh berbagai pihak. Hal ini dapat dikatan sebagai hasil revolusi yang lebih mendekat kepada kebaikan dan kemaslahatan, sebagaimana dituliskan oleh sappeami revolusi mental adalah mengubah karakter, cara pandang, berpikir, bekerja, meyakini dengan melakukan perilaku dan tindakan yang baik dalam kehidupan sehari-hari. Zakat profesi merupakan sebagian harta yang wajib dikeluarkan oleh setiap muslim dari gaji atau penghasilannya. Peraturan bupati Polewali Mandar Provinsi Sulawesi Barat telah mengeluarkan peraturan Bupati Nomor 9 tahun 2019 tetang tata cara pengumpulan zakat profesi bagi aparatur sipil negara di Kabupaten polewali mandar. Bedasarkan hal tersebut artikel ini meneliti sistem pengelolaan dana zakat profesi pada badan amil zakat nasional kabupaten polewali mandar.

\section{METODE PENELITIAN}

Penelitian ini merupakan penelitian lapangan yang bersifat kualitatif, Metodologi kualitatif merupakan prosedur penelitian yang menghasilkan data deskriptif berupa 
kata-kata tertulis atau lisan dari orang-orang atauperilaku yang diamati. Pendekatannya diarahkan pada latar dan individu secara holistik (utuh) (Lexi J Moleong, 2015) . Maksud dari penelitian lapangan adalah penelitian yang datanya penulis peroleh dari lapangan dilakukan di kantor Badan Amil Zakat Nasional (BAZNAS) Kab. Polewali Mandar yang beralamat di Jl. Mr. Muh. Yamin, Kompleks Mesjid AgungSyuhada Kel. Darma, Kec. Polewali, Kabupaten Polewali Mandar, Sulawesi Barat. Data diperoleh melalui wawancara, dokumentasi serta observasi. Kemudian dilakukan reduksi data, penyajian data serta verifikasi data.

\section{HASIL DAN PEMBAHASAN}

Setiap orang muslim mengakui bahwa zakat merupakan salah satu penyangga tegaknya Islam yang wajib di tunaikan (Muhammad; 2007). Di negara Arab modern, istilah profesi diterjemahkan dalam dua kosakata bahasa arab. Pertama al-minhah, kata ini sering dipakai untuk menunjuk pekerjaan yang mengandalkan otak. Karena itu kaum profesional disebut dengan al-mihaniyyun atau ashab al-minhah. Misalnya, pengacara, penulis, dokter, pakar hukum, pekerja kantoran dan lain sebagainya. Kedua ialah al-hirfah, kata ini lebih ditunjukkan untuk pekerjaan yang mengandalkan otot. Misalnya, pengrajin, pandai besi, tukang jahit, kuli bangunan, dan sebagainya (Deny Setiawan; 2011).

Bagian pengumpulan BAZNAS Kabupaten Polewali Mandar menentukan sasaran muzakki yang akan dijadikan objek aktivitas pengumpulan untuk menggalang dana zakat profesi sebagaimana yang telah diutarakan oleh Bapak Liwauddin padahari Rabu tanggal 3 Februari 2021.

"Sasaran pengumpulan dana zakat profesi tentu masyarakat profesi. Sehingga perencanaan dirumuskan untuk menarik seluruh masyarakat profesi di Kabupaten Polewali Mandar agar menyalurkan zakatnya melalui BAZNAS Kota Bukittinggi. Namun kondisi objektif yang ditemukan dilapangan adalah berupa dana zakat profesi yang belum dikumpulkan secara keseluruhan oleh wajib zakat kepada BAZNAS, sehingga akan membuat kemungkinan bagi kami bahwa itu akan menyebabkan perencanaan dan sasaran tidak tercapai sesuai yang dirumuskan."

Sasaran pengumpulan dana zakat profesi, bidang pengumpulan BAZNAS

Kabupaten Polewali Mandar bisa berfokus terhadap sasaran yang telah dirumuskan 
Journal of Economic, Public, and Accounting (JEPA)

ISSN Online 2623-2472

Vol. 3 No.2 April 2021, hlmn. 149-162

ISSN Cetak 2715-8977

tersebut. Namun fakta di lapangan menyatakan bahwa kesadaran masyarakat profesi untuk menyalurkan dana zakat profesinya melalui BAZNAS Kabupaten Polewali Mandar dapat menjadi faktor pendorong tidak tercapainya perencanaan dan sasaran yang sudah ditentukan.

Penetapan jadwal pengumpulan dana zakat profesi secara umum telah disusun dalan RKAT (Rencana Kerja dan Anggaran Tahunan) sebagaimana dikatakan oleh Bapak Liwauddin pada tanggal 3 Februari 2021.

"Pola penjadwalan itu disusun setiap tahunnya, seperti yang disusun dalam RKAT. Jadi disitu sudah jelas jadwal untuk melaksanakan sosialisasi,

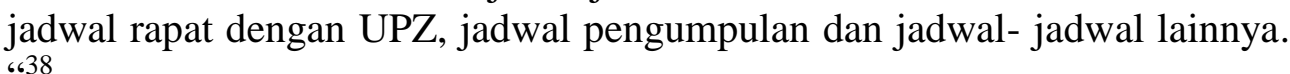

Seperti yang dipaparkan oleh Bapak Liwauddi bahwa seluruh kegiatan bidang pengumpulan untuk mengumpulkan dana zakat profesi dalam setahun sudah dijadwalkan secara umum, mulai dari awal sampai akhir tahun. Sedangkan waktu dan lokasi pengumpulan dana zakat profesi per bulannya itu dilaksanakan setiap awal bulan.

Meskipun muzakki di Kabupaten Polewali Mandar banyak berasal dari profesi PNS, masih banyak profesi lain yang menyalurkan zakatnya melalui BAZNAS Kabupaten Polewali Mandar. Hal itu tercatat dalam dokumen laporan pengelolaan zakat secara keseluruhan di BAZNAS Kabupaten Polewali Manadar tahun 2020 sebagai berikut:

Tabel 1

Persentase pengumpulam zakat tahun 2020

\begin{tabular}{|c|c|c|}
\hline NO & Nama/Musakki & Persentase Zakat \\
\hline 1 & Zakat Pribadi & $17 \%$ \\
\hline 2 & PNS Pemda & $27 \%$ \\
\hline 3 & Dokter & $1 \%$ \\
\hline 4 & PNS Kecematan & $13 \%$ \\
\hline 5 & SD Kecematan Matakali & $6 \%$ \\
\hline 6 & SD Kecematan Polewali & $7 \%$ \\
\hline 7 & SD Kecematan Balanipa & $5 \%$ \\
\hline
\end{tabular}




\begin{tabular}{|c|c|c|}
\hline 8 & SMP & $12 \%$ \\
\hline 9 & Kemenag dan Madrasah & $7 \%$ \\
\hline 10 & Intansi lainnya & $5 \%$ \\
\hline & TOTAL & $100 \%$ \\
\hline
\end{tabular}

Pengumpulan zakat BAZNAS Kabupaten Polewali Mandar menentukan visi misi yang ingin mewujudkan BAZNAS Kabupaten Polewali Mandar yang Baznas Kabupaten Polewali Mandar Yang Amanah, Inovatif, Dan Modern. Namun ada hal yang perlu dievaluasi mengenai pencapaian dan pelasanakan dari visi misi itu sendiri, karena masih kurangnya kesadaran sebagian msyarakat untuk menyalurkan zakat profesinya melalui BAZNAS Kabupaten Polewali Mandar.

Pengumpulan dana zakat profesi, bidang pengumpulan BAZNAS Kabupaten Polewali Mandar memiliki bebrapa program melalui sosialisasi, media cetak maupun elektronik, kemudian ada melalui tatap muka secara langsungdan juga ada melalui baliho- baliho. Dalam pelaksanaanya tahapan perencanaan, pengorganisasian, Penggerakan dan pengawasan dalam pendistribusaian/pendayagunaan dana zakat profesi memiliki langkah-langkah tertentu untuk mendorong kesuksesan aktifitas pendistribusian sebagai berikut:

a. Perencanaan

Rencana adalah produk perencanaan, sedangkaan perencanaan adalah fungsi dasar (fundamental) karena organizing, directing, controling, evaluating, dan reporting harus terlebih dahulu direncanakan (S.P hasibuan ;2011). Cara yang dilakukan oleh BAZNAS Polewali Mandar dalam membaca situasi dan kondisi di lapangan ketika akan melaksanakan aktivitas pendistribusian dan pedayagunaan dana zakat membaca data mustahiq dan memastikan data tersebut telah akurat atau belum. Kemudian cepat berpikir, meramalkan dan mengantisipasi penambahan ataupun pengurangan penyaluran dana zakat profesi. Dengan meramalkan dan mengantisipasi penambahan dan pengurangan mustahiq zakat profesi, bidang pendistribusian dan pendayagunaan bisa memperkirakan jumlah 
zakat profesi yang akan disalurkan dengan optimal. pendistribusian dan pendayagunaan BAZNAS Polewali Mandar menetukan mustahiq yang akan dijadikan objek untuk aktivitas pendistribusian dan pendayagunaan dana zakat profesi. Dana zakat profesi dilasurkan kepada mustahiq di lingkungan dana zakat profesi itu dikumpulkan. Jika dana zakat profesi dikumpulkan dikantor, maka mustahiq yang ada di kantor tersebut adalah mustahiq yang diperioritaskan untuk menerima dana zakat profesi tersebut. Contohnya pegawai honor, penjaga kantor, cleaning servis dan profesi lain jika tergolong kepada fakir miskin atau mustahiq diprioritaskan. Persentase tersebut dapat disimpulkan dalam tabel berikut:

\section{Tabel 2}

Persentase Pendistribusian/Pendayagunaan Dana Zakat Profesi

\begin{tabular}{|c|c|c|}
\hline NO & Keterangan & Persentase \\
\hline 1 & Didistribusikan & $87,5 \%$ \\
\hline 2 & Hak Amil & $12,5 \%$ \\
\hline & Jumlah & $100 \%$ \\
\hline
\end{tabular}

Sumber: Hasil wawancara dengan Bapak Ahmad Fadhl Al Madhaly pada tanggal10 Februari 2021

b. Pengorganisasian

Perumusan dan pembagian tugas kerja, bidang pengumpul hanya memiliki satu orang ketua yaitu wakil ketua I BAZNAS Polewali Mandar dan memiliki satu orang pegawai amil tetap, Namun jika perumusan dan pembagian tugas kerja melebihi kemampuan SDM (Sumber Daya Manusia) yang ada maka ada amil sementara yang direkrut oleh BAZNAS Polewali Mandar. bidang pengumpulan BASNAZ PolewaliMandar hanya memiliki dua orang sebagai SDM tetap di bidang pengumpulandan masih membutuhkan SDM tambahan agar pembagian kerja lebih pesifik.Karena dengan SDM seadanya maka kreatifitas atau ide-ide sulit untuk diciptakan. Kurangnya SDM juga merupakan salah satu faktor sulitnya mencapai pendataan dan pengumpulan yang tinggi. 
Pemberian wewenang dalam bidang pengumpulan dana zakat profesi di BAZNAS Polewali Mandar disesuaikan dengan strukturisasi yang ada dari ketua kepada a milnya, selain itu wewenang pengumpulan zakat profesi juga ada UPZ, camat dan lurah selaku pihak yang telah dipercayakan melalui koordinasi oleh BAZNAS Polewali Mandar untuk membantu aktivitas bidang pengumpulan terutama dalam megoptimalkan pedataan muzakki. Untuk optimal lain seperti kontraktor, notaris,dokter, dan lainnya langsung menjadi tanggung jawab amil BAZNAS Polewali Mandar. Pihak BAZNAS Polewali Mandar yang langsung melakukan sosialisasi, penyebaran email, melalui telepon, dan lain-lain.

c. Pelaksanaan

Pelaksanaan aktivitas bidang pengumpulan dengan adanya penggerakan dari ketua bidang pengumpulan, lalu koordinasi diteruskan kepada UPZ, SKPD yang ada di Polewali Mandar. Untuk menarik kesadaran masyarakat tentang adanya zakat profesi maka langkah selanjutnya yang dilaksanakan oleh BAZNAS adalah melasanakan sosialisasi, Sosialisasi mengenai zakat profesi telah dilaksanakan oleh BAZNAS Polewali Mandar. Namun kesadaran muzakki masih rendah untuk menyalurkan penghasilannya yang wajib dizakatkan. Oleh karena itu untuk mencapai visi dan misi BAZNAS harus melakukan sosialisasi lebih sering dan berupaya meningkatkan kepercayaan muzakki untuk berzakat melalui BAZNAS Polewali Mandar. Pengumpulan dana zakat profesi dilaksanakan dengan berbagai metode. Zakat profesi tersebut ada yang diantar langsung ke BAZNAS Polewali Mandar, dikirim melalui bank, dikirim melalui bendahara SKPD terkait dan melalui layanan telepon.

Berdasarkan laporan pengelolaan zakat BAZNAS Polewali Mandar pada tahun 2020, pengumpulan dana zakat profesi belum bisa dikatakan maksimal karena potensi zakat profesi di Polewali Mandar cikup banyak. Potensi tersebut padat dilihat pada tabel dibawah ini.

Tabel 3

Potensi Zakat Profesi Polewali Mandar 


\begin{tabular}{|c|c|c|}
\hline NO & Segmen & Potensi \\
\hline 1 & PNS Pemda & 135 Orang \\
\hline 2 & Guru SMP & 1000 Orang \\
\hline 3 & Guru SD & 1700 Orang \\
\hline 4 & Profesi Dokter & 2 Orang \\
\hline 5 & Profesi lainnya & 150 Orang \\
\hline 6 & Pribadi & 55.572 Orang \\
\hline
\end{tabular}

Sumber: Laporan pengelolaan zakat BAZNAS Kabupaten Polewali Mandar tahun 2020 Pendistribusian zakat, BAZNAS Kabupaten Polewali Mandar menyalurkan zakat melalui lima program yaitu sebagai berikut:

Tabel 4

\section{Persentase penyaluran zakat profesi 2020}

\begin{tabular}{|c|c|c|}
\hline NO & Program & Persentase \\
\hline 1 & Kemanusiaan & $19 \%$ \\
\hline 2 & Pendidikan & $16 \%$ \\
\hline 3 & Kesehatan & $21 \%$ \\
\hline 4 & Ekonomi & $32 \%$ \\
\hline 5 & Dakwah & $12 \%$ \\
\hline & TOTAL & $100 \%$ \\
\hline
\end{tabular}

Sumber: Laporan Pengelolaan Dana Zakat BAZNAS Kabupaten Polewali Mandartahun 2020.

d. Pengawasan

Langkah awal pengawasan pengumpulan dana zakat profesi yang dilakukan BAZNAS Polewali Mandar adalah menetapkan standar, terutama standar operasional prosedur. Prosedur operasional yang standar awal dalam mengawasi pelaksanaan setiap kegiatan, karena standar operasional prosedur memuuat semua prosedur untuk setiap hal yang dilakukan dalam organisasi yang membuat standar operasional tersebut. Sehingga setiap kegiatan bisa terlaksana secara efektif dan efesien.

Pemeriksaan pengumpulan zakat profesi sebagai salah satu bagian dari pengawasan, bidan pengumpulan BAZNAS Polewali Mandar melakukan 
monitoring terhadap UPZ yang membuat pengumpulan dana zakat. Sebagaimana yang dipaparkan oleh Bapak Liwauddin pada tanggal 9 Februari 2021.

"Untuk memastikan kita kan memantau setiap bulan misalnya sebagai contoh dinas apakah dia sudah mengumpulkan zakat atau belum. Kalau belum langsung kita tanyakan appa pernasalahan yang dialami oleh diknas ataupun bendaharawan gaji dari diknas itu sendiri." 47

Evaluasi pengumpulan dana zakat profesi, bidang pengumpulan BAZNAS Polewali Mandar melaksanakan kegiatan atau rapat evaluasi bulanan, Selain evaluasi melalui pertemuan dan rapat, laporan yang dibuat oleh BAZNAS Polewali Mandar baik bulanan maupun tahunanjuga telah menjadi wadah evaluasi yang dapat memberikan input besar dalam manajemen pengumpulan dana zakat profesi.

Standar adalah salah faktor penetu keberhasilan setiap kegiatan maupun keberhasilan setiap organisasi, menurut BAZNAS Kabupaten Polewali Mandar, keberhasilan mereka mencapai banyak prestasi di tingkat daerah sampai tingkat nasional tidak lepas dari peran standar yang mereka gunakan, yaitu ISO 9001 2008. Penerapan ISO 99012008 merupakan hal yang paling berpengaruh dalam setiap prestasi yang dicapai oleh BAZNAS Kabupaten Polewali Mandar. Selain ISO 9001 2008, penerapan standar akuntansi keuangan PSAK 109 juga merupakan hal penting dalam tertib administrasi BAZNAS Kabupaten Polewali Mandar. Menurut Bapak Ahmad Fadhl Al Madhaly selaku wakil ketua II BAZNAS Kabupaten Polewali Mandar selain tertib administrasi, ketetapan sasaran pendistribusian juga merupakan nilai tambah bagi BAZNAS Kabupaten Polewali Mandar dalam meraih berbagai prestasi.

Zakat yang sudah didistribusikan memalaui pihak yang berkoordinasi dengan BAZNAS Kabupaten Polewali Mandar diawasi kembali kepastian pendistribusiannya melalui mintoring

Pelaporan merupakan unsur penting dalam pengelolaan, yaitu dalam fungsi pengawasan (controlling). Ada dua verifikasi penerimaan dimulai sejak dana 
ditranfer dari muzakki hingga masuk ke lembaga zakat, sedangkan verifikasi pengeluaran dicermati sejak diajukan hingga pencairan dana. BAZNAS Kabupaten Polewali Mandar mencatat semua data tersebut dalam sebuah aplikasi bernama SIMBA atau Sistem Manajemen Informasi BAZNAS. Beberapa fitur yang dimiliki SiMBA dalam menghimpun dana zakat dan ifak/sedekah, penyaluran dana zakat dan infak/sedekah, dan juga memuat berbagai jenis lapora. Standar akuntansi yang diapaki oleh BAZNAS Kota Bukittinggi adalah standar wajib keuangan yaitu PSAK 109. Berdasarkan undang-undang republik indonesia nomor 23 tahun 2011 bab 3 pasal 29 ayat 1 bahwa BAZNAS Kabupaten atau kota wajib menyampaikan laporan pelaksanaan pengelolaan zakat, infak, sedekah, dan dana sosial keagamaan lainnya kepada BAZNAS provinsi dan pemerintah daerah secara berkala. BAZNAS Kabupaten Polewali Mandar sudah menyampaikan laporan tersebut secara berkala atau dilaporkan setiap semester atau enam bulan sekali, sesuai dengan Peraturan Pemerintah nomor 14 tahun 2014 bab 9 pasal 71 ayat 1. BAZNAS Kabupaten Polewali Mandar memberikan laporan tersebut setiap tanggal 5 bulan berjalan.

Berdasarkan Undang-Undang Republik Indonesia Laporan Pengelolaan Zakat BAZNAS Kabupaten polewali Mandar tahun 2020 memuat beberapa laporan, diantaranya adalah:

a. Realisasi pengumpulan zakat tahun 2020

b. Realisasi penyaluran zakat tahun 2020

c. Laporan perubahan dana termanfaatkan tahun 2020

d. Laporan arus kas tahun 2020

e. Neraca 2020

f. Laporan penerimaan dan penggunaan dana amil tahun 2020

g. Rencana anggaran biaya penggunaan dana amil tahun 2020 


\section{KESIMPULAN}

Manajemen pengumpulan dana zakat profesi di BAZNAS Kabupaten Polewali Mandar belum maksimal, hal itu bisa dilihat dari dari pencapaian visi dan misi bidang pengumpulan yaitu meningkatkan kesadaran musakki dalam mengumpulkan mengumpulkan zakat dari penghasilannya ke BAZNAS Kabupaten Polewali Mandar. Visi dan misi itu belum tercapai karena masih banyak muzakki belum mengumpulkan zakatnya melaui BAZNAS Kabupaten Polewali Mandar. Manajemen pendistribusian dan pendayagunaan dana zakat Profesi di BAZNAS Kabupaten Polewali Mandar telah layak mendapatkan nilai yang baik. Perencanaan pendistribusian dan pengorganisasian juga sudah matang. Pelaksanaan pendistrbusian dan pendayagunaan dana zakat profesi pada BAZNAS Kabupaten polewali Mandar dilaksanakan sesuai dengan ketentuan pendistribusian dan sesuai dengan seluruh regulasi yang mengatur pendistribusian zakat pada BAZNAS Kabupaten Polewali Mandar. Zakat didistribusikan sekitar 90\% dari total pengumpulan setiap tahunnya. Contohnya pada tahun 2020, zakat didistribusikan sebesar 2,04 Milyar dari total pengumpulan sebesar 3 Milyar. Terakhir adalah tahap pengawasan, BAZNAS Kabupaten Polewali Mandar menerapkan standar bertaraf internasional yaitu ISO 90012008 sebagai sistem manajemen mutu.

\section{DAFTAR PUSTAKA}

Andri, Soemitra. Bank dan Lembaga Keuangan Syariah. Jakarta: KencanaPrenada Media Grop. 2013

Kementerian Agama RI, Al-Qur'an Terjemah dan Penjelasan. Solo: PT. Tiga Searngkai Pustaka Mandiri. 2016

Lexy, J. Moleong. Metodologi Penelitian Kualitatif. Bandung: Remaja Rosdakarya, 2015.

Malayu S.P Hasibuan, Manajemen Dasar, Pengertian, dan Masalah. Jakarta:PT Bumi Aksara, 2011.

Muhammad. Aspek Hukum dalam Muamalat. Depok: Graha Ilmu 2007

Qardawi Yusuf, Hukum Zakat.2015. Bandung : Pustaka Mizan. 
Journal of Economic, Public, and Accounting (JEPA)

ISSN Online 2623-2472

Vol. 3 No.2 April 2021, hlmn. 149-162

ISSN Cetak 2715-8977

Sappeami, Sappeami. "Revolusi Mental Dalam Menerapkan Sistem Ekonomi Islam." Al-Intaj : Jurnal Ekonomi Dan Perbankan Syariah 4, no. 2 (October 9, 2018). https://doi.org/10.29300/aij.v4i2.1215.

Setiawan, Deny. Zakat Profesi dalam Pandangan Islam. Jurnal Sosial Ekonomi Pembangunan, Vol : 1, No.2 Maret 2011 